\title{
Environment Development Based on Local Community, Case of "Relawan Kampung," Banten, Indonesia
}

\author{
Ika Arinia Indriyany ${ }^{I}, M$ Dian Hikmawan $^{1 *}, M o h$. Rizky Godjali ${ }^{1}$, and Mahpudin ${ }^{l}$ \\ ${ }^{1}$ Government Department, University of Sultan Ageng Tirtayasa, Indonesia
}

\begin{abstract}
This research describes how the infrastructure development was carried out by "Relawan Kampung" (Village Volunteers), Banten, Indonesia. "Relawan Kampung" is here to overcome the anxiety of unequal development carried out by the government, which hinders people's mobility. The development they are doing is carried out by paying attention to the sustainability of the surrounding environment and involving the local community as the key development actors. Using the theory of Development Based Community and Case Study Methods, the research results show that the independence of the "Relawan Kampung" from the government, which is reflected in the independence of funds, actually shows the success of a development. Since its establishment in 2012, "Relawan Kampung" has been able to build hundreds of bridges. This is an excellent example of how empowered civil society can meet its own needs without government assistance.
\end{abstract}

\section{Introduction}

Infrastructure development is believed to be one of the main factors for the success of economic development [1]. Supported by infrastructure development that reaches all corners of the country, the wheels of the economy will be able to move, and the economic indicators set by the government can be fulfilled. This infrastructure development is one of the government's obligations that must be carried out in the community [2,3]. However, sometimes, the development that has been carried out has neglected environmental sustainability.

Walhi, quoted by CNN Indonesia, said that President Jokowi's development has often neglected environmental sustainability and the interests of the community [4]. This is shown by changing the function of agricultural land, displacing people, and using nonrenewable energy. Another example is the construction of the Solo-Kertosono Toll Road, which is considered environmentally unfriendly because it ignores the AMDAL, such as increased air pollution, rice irrigation channels that are not functioning normally, and access to rice fields which are the place of people's livelihoods is also closed [5].

Neglect of the environment and the community's interests occurs because the community is not involved in the development process, from planning to implementation. This is because the government's primary focus is to increase economic growth alone, not because of the people's need for infrastructure in their regions. The power relations that are built between

\footnotetext{
* Corresponding Author : dian.hikmawan@untirta.ac.id
} 
the government and the community tend to be top-down, formality, and elitist so that the development process fails [5] [6]. This is undoubtedly contrary to the principle of community participation in decentralization, where the community has the right to determine their needs and voice opinions according to the needs of local communities.

It is precise with the involvement of the local community that social change and the urgency of development can be maximally achieved. In Pandeglang, Laz Harfa changed the community's lifestyle from initially having a habit of defecating openly to having a clean and healthy lifestyle by defecating in a latrine [8]. The governance of the palm oil industry initiated by FOKSBI and ISPO has proven to have a significant role in increasing the sustainable palm oil industry because it uses multi stakeholders partnership approach, including civil society [9]. Local community concerns are formed through their persuasive communication starting from behavior, attitudes, and perspectives to adopt a clean and healthy lifestyle. In Purbalingga, the involvement of women in processing household waste into valuable recyclables can reduce waste [10]. Through women's leadership, they improve the literacy culture related to waste and how to process waste into something useful in their lives. Further involvement of the local community can even be done by holding a cooperation forum between several actors ranging from the government, private sector and the community [11] [12]. This cooperation forum ensures two things, first how the community has access to clean water and encourages policies related to water management so that drought does not occur, especially during the dry season.

The existence of local communities in guarding environmental issues in their area cannot be ignored. Several studies have shown that local communities' rejection of the destruction of their environment is effective through their social movements. Mining activities of mineral $\mathrm{C}$ in Bojonegara which damaged the mountains and the surrounding environment gave birth to a social movement by the community (KMBPL / Bojonegara Community Care for the environment [13]. Research shows that the movement carried out by civil society can maintain the sustainability of their environment based on religion [14]. Although not against the state but corporations, the movement carried out by the Muslim Community and led by a local religious leader effectively stops the construction of drinking water factories that threaten the clean water sources of the local community.

Development is needed, but development that pays attention to environmental sustainability and involves local communities is a challenge that must be done. Another challenge is ensuring that this development can be enjoyed by all people in all corners of the country. It was because of this concern that "Relawan Kampung" came. "Relawan Kampung" comes from the anxiety that mobility often constrains people in disadvantaged areas due to disconnected access between regions. The founder of "Relawan Kampung," Arif Kirdiat, was initially worried about the infrastructure condition in Banten Province, which was unable to reach the outer areas. The mileage, which should have been shortened, requires people to travel long distances to move between villages separated by rivers. However, Arif is aware that if he waits for financial assistance from the government, the process will take a long time or may not even be approved for funding. Because the government usually refers to the RPJMD, which contains strategic programs and development urgency that must come first. The presence of a bridge will make the daily life of the local community easier. Therefore, in 2019, Arief established a "Village Volunteer" Community with the tagline "Better to Light Candles, Than to Blame Darkness." Instead of being busy blaming the government for the funds that have not been disbursed, "Relawan Kampung" prefers to collect separate donations to build bridges by involving the local community. Currently, 
Village Volunteers have built hundreds of bridges in Banten Province and have expanded to other provinces in Java, Sumatra, and NTB. This research offers a new approach to looking at development problems. Development, which the government has always born, can be initiated by a civil society whose implementation is carried out in cooperation with the economic society and local communities, which of course still pay attention to environmental sustainability in its development.

\section{Theoretical Framework}

\subsection{Community-Based Development}

Community-based development is a concept introduced by the World Bank as an activity that actively involves affected parties from the design to management [15]. In its development, this concept then expanded into community-driven development, when the community had complete control over project management which was carried out both in the decision-making process and in financial management.

This concept was then widely used because it was considered to bring benefits such as shifting the power relations previously created a client patron pattern between the donor and the donor-recipient. Donor recipients usually do not have complete control over the activities they carry out. Using this concept, they are fully responsible for the sustainability of the project and the use of the budget.

Some indicators that can be used to see community-based development are [15]:

\section{a. Participation}

Participation requires active initiation from community members from planning activities to implementation. Participation indicates that the community can independently voice their interests, choices, and actions to show their position as an empowered community. Participation closes the opportunity for negative things to occur due to client patron relationships such as corruption or personal gain-seeking activities.

\section{b. Community}

The World Bank divides the community into two things, namely culturally and politically. Culturally, communities can be seen when they hit administrative boundaries that differentiate them from one another, geographic administrative boundaries, for example, cultural, religious, ethnic communities, etc. Second, politically, communities are distinguished by their position in the local structure and their power both socially and economically. It is essential to distinguish the community's character because it will impact the activities they carry out and how social identities are formed. 


\title{
c. Social Capital
}

Social capital is an essential asset in project implementation, such as trusts, norms, and networks [10]. Social capital talks about how community members, namely individuals, can build strong bonds within their group and build otherness with other groups. Social capital includes photographing how power relations are reflected in social life to see which actors play the most role in the decision-making process. Is it the donor or the local community?

\subsection{Environment Partnership Model}

A collaborative approach, especially in responding to environmental issues, is needed to ensure that the development is carried out sustainably. The Partnership Model requires the involvement of 2 or more organizations with different interests but have the opportunity to formulate common goals [16]. When discussing eco-efficiency, partnerships can be translated as a vehicle for an economic society to continue implementing its valuable innovations. This innovation is then carried out by civil society to improve the quality of their lives.

Collaboration in ensuring sustainability requires actors from various levels, such as actors with different backgrounds, different functions, different resources, etc. These different backgrounds are then used to discuss the problem from different perspectives to formulate goals beyond their limited version. So that goals that were previously impossible, collaboration becomes possible. In the environmental field, it is essential to see collaboration between actors responding to environmental issues. The goal is that the environment can be maintained under its initial function.

Partnership demands independence between the actors involved. When they are treated equally even though they have different backgrounds, they will voice their respective interests and find alternative actions to achieve common goals. This common goal will not be achieved when the position is power-based, such as a client patron. To achieve this, the first step that needs to be done is to create a standard definition and understanding of the problem at hand [16].

\section{Result and Discussion}

\subsection{Institutionalism for Environment Sustainability}

\begin{abstract}
"Relawan Kampung" as a societal community is based on a commitment to environmental sustainability, on environmentalism approach, debating on civic-republican engagement become more practicing on duties or moral obligation [17]. Of course, debating the duties and moral obligations bring us to how long and much "Relawan Kampung" represents their commitment to sustainability. To perceive the subject position of "Relawan Kampung," who tries to represent the sustainability issues on environment in local government, especially in Banten.
\end{abstract}

"Relawan Kampung" should be realized as forming a societal community that is concerned with civic-republican in practicing public engagement [18]. On the institutionalism view, 
"Relawan Kampung" is the transformation of ecological citizenship that tries to use community resources and attention to local issues. As a potential community to brings the transformation in public discourse [19]. If we see "Relawan Kampung" has an intense activity on developmentalism in local Banten. In their activity, they do what the government does not, on practicing to develop the local area in Banten. Moreover, most of the area is a remote area far from the central city of Banten. It is also "Relawan Kampung," giving attention to the equality on developmentalism and the accessibility for the societalcommunity in a remote area in Banten.

On "Relawan Kampung" analysis, we categorize this community as organizational solid and significantly influence the government side policy. At least now, less than 200 bridges were built by "Relawan Kampung," and all the resources are supported by the private sector through corporate social responsibility (CSR) and collecting donations from public engagement. To make sense of this "Relawan Kampung" activity, they become subject to political agenda for getting public attention. We can perceive that "Relawan Kampung" succeeds in institutionalizing their community and transforming their activity into public collective action for environmental sustainability.

\subsection{Transformation of "Relawan Kampung"}

Collaboration carried out by "Relawan Kampung" with donors and local communities are based on trust. Having an equal position, all parties involved in building a social and environmental infrastructure project also have an actual, influential, and significant role. The "Village Volunteer" team ensures that every project and activity carried out needs to involve the local community. Roles are given to local communities, including mapping the basic needs of the project to be undertaken, proposing bridge designs, socialization and social security (maintaining conduciveness of project work from disruption to community activities), and providing human resources to assist project completion. The role that the community plays is carried out voluntarily. Except for the bridge construction, core workers are paid a compensation wage for the labor and time given. However, there were not many, only a few people. More people help work on bridges and other social projects voluntarily, without coercion. Teens, adult men, mothers, and children were eagerly involved in carrying out the project initiated by "Relawan Kampung." They help according to their abilities.

The active participation of residents based on trust is an essential social capital asset in building this collaboration. Trust is at the core of building the strong bonds that occur within the community groups where the bridge construction occurs. The local community believes that the construction of this bridge is a social and environmental project that must be completed by the residents themselves in cooperation. The local community understands that the bridge builder is not a project originating from the government, uses state funds, has a negative perception of being corrupted and controlled unilaterally by certain actors. The construction of the bridge must be fully supported to completion.

The active participation of citizens will build trust in donors. The budget allocation provided is not only aimed at completing one output in the form of a bridge or one activity. More than that, the funds spent must have long-term outcomes. Beneficial for residents in a wide range. The active participation of residents in project work is a very positive initial picture as an indicator of a good effect. So that the donor's goal of empowering the 
community can be realized, conditions for participating citizens, empowered citizens will make donors believe that the funds that have been spent have been used to improve living standards, social activities, and the economical turnover of the community in the future. The results of the evaluation of fund management by donors will be of good value. This makes company officials and donor agencies happy. It could even recommend providing sustainable funding in the future.

The active participation of residents to help work on the bridge project can also build relationships with the products produced and the local environment. The bridge built because of the empowerment process and the involvement of the community's role is considered to be able to last a long time. The bridge will be maintained and guarded by the local community so that it is not damaged. The bridge is in clean condition and has remained in good shape for a long time. The maintenance process does not require the further expenditure of funds. All done voluntarily. The community views the new bridge as an essential part of it. The new bridge has built connectivity between spaces, between interests, increasing social mobility. Maintaining bridges means protecting the living and working environment to be good.

The existence and role of "Relawan Kampung" are not just about presenting a bridge. Nevertheless, it can become a bridge that connects donors and the community. "Relawan Kampung" also works voluntarily. He is not a brokerage group. "Relawan Kampung” tries to create a balanced partnership in completing a project. All actors involved have independence in carrying out their respective interests. Those involved in a project have the right to convey important views, which are the primary needs or goals. The local community wants the bridge to be built solidly. However, donors also have other objectives that residents do not understand. Sometimes there are different perspectives. "Relawan Kampung" can be excellent facilitators. They are prioritizing the deliberation mechanism between actors in finding solutions. "Relawan Kampung" was able to convince donor donors to contribute sufficient funds to build one or more bridges. The development process involves the local community. The materials for building the bridge also came from shops nearby the area. "Relawan Kampung" does not recommend using environmental materials in building bridges. For example, sand, foundation stone, and split stone. Besides having the quality that is not up to standard and not the same. Taking materials directly from the surrounding environment will have an impact on environmental destruction. While doing community empowerment, "Relawan Kampung" also provides good education about environmental preservation to residents.

Since 2012 more than 100 bridges have been built through the Partnership Environment Model initiated by "Relawan Kampung." This is supported by the involvement of dozens of economic societies as donors. They are starting from private companies, educational institutions, individual donations to the government of the United Arab Emirates. "Relawan Kampung” started a small project construction of a suspension bridge in Cimanggu Village, Ujung Kulon National Park. A remote village with poor road and bridge access in Pandeglang Regency. Development funds come from various individual donations and the Networking Institution of the Head of "Relawan Kampung," Mr. Arif Kirdiat. Success for its first bridge project, the "Village Volunteer" social movement received sympathy and appreciation from many parties, from within and outside the country. Plus the packaging of good publications, "Relawan Kampung" gained the trust to manage more and more funds from several companies. The priority target areas for the "Relawan Kampung" program are Pandeglang and Lebak districts. Two government areas with the most severe infrastructure 
development problems are in Banten Province. The area is vast, and the people live in scattered zones. The local government does not have sufficient funds to meet all the road and bridge infrastructure needs for its citizens. "Relawan Kampung" builds bridges in the village through which large and medium rivers flow. In that area, there is no bridge or the bridge is badly damaged. This condition makes the social mobility of the residents ineffective. It wastes a lot of time and effort. Sometimes the children even force themselves to cross the broken bridge by hanging on to go back to school—an ironic situation.

Currently, "Relawan Kampung" has expanded the program's target area outside Banten Province. "Relawan Kampung" have built a bridge in Kutalimbaru, Deli Serdang district, North Sumatra Province. There is also a bridge built in the Walenrang area, Luwu Regency, South Sulawesi Province. Next, the bridge lies in the village area of Lunyuk, Sumbawa Regency, West Nusa Tenggara Province. Not only building bridges in remote areas and having poor access infrastructure but "Relawan Kampung" also build bridges in areas affected by natural disasters as was done in the Sajira area, Lebak Regency. This area is the location of the flash flood disaster in 2019. Another Social Project, "Relawan Kampung," is also involved in post-disaster environmental recovery activities. Such as helping to restore residents' condition and the environmental conditions of the 2018 Sunda Strait tsunami disaster. All environmental development activities initiated by "Relawan Kampung" always have the same pattern, namely the Partnership model. "Relawan Kampung" will invite the local community to participate in solving an environmental problem it faces. The ability of "Relawan Kampung" to invite residents to participate is to build trust and confidence in a better condition in the future.

\section{Conclusion}

"Relawan Kampung" is one of the ideal models of community empowerment. This can be seen from the empowerment model and approach carried out in working on social projects. The empowerment model involves the participation of local communities to ensure that the social projects carried out do not violate the public interest to generate maximum social benefits. The involvement of local communities in development is essential to build collective trust to feel responsible for maintaining development outcomes. In addition, the social projects that are carried out prioritize environmental sustainability. The primary commitment of "Relawan Kampung" is development without damaging the environment. Thus, the social projects carried out reflect community-based development practices and the Environment Partnership Model.

This model-building approach is effective in expanding long-term social projects. In addition, the development model that has been implemented has succeeded in changing power relations radically from being patronage to partners. This has led to the existence of "Relawan Kampung" to continue to this day. "Relawan Kampung" can show independence without depending on funds from the government. The presence of "Relawan Kampung" fills the empty spaces that cannot be provided by the government, especially in terms of infrastructure provision. The main social project of "Relawan Kampung" is building bridges. A bridge that does not only mean a physical building but "Relawan Kampung" is capable of being a bridge itself that connects the interests of citizens, government and the private sector. 
"Relawan Kampung" are the best role models in practicing the community-based development approach and the Environment Partnership Model. In the future, this kind of capital will become an essential discourse in answering debates on development and environmental sustainability issues. The two often exclude each other, which results in exploitation of the environment, marginalization of citizens, or resistance of the social community.

\section{References}

1. Bappenas, Bappenas (2009)

2. Y. Yonatan, N. Fitriyah, and A. Margono, J. Adm. Reform 2, (2014)

3. H. B. Melati, J. Contemp. Gov. Public Policy 1, 108 (2020)

4. B. Wiwoho, CNN Indones. (2017)

5. U. Khasanah, N. Nugraha, and W. Kokotiasa, Citizenship, J. Pancasila Dan Kewarganegaraan 5, (2017)

6. R. Hidayat, H. Hendra, and M. Iptidaiyah, J. Gov. 4, 45 (2019)

7. D. Faedlulloh, J. Gov. 3, 1 (2018)

8. A. Malik and L. D. Putri, Int. J. Demos 2, (2020)

9. A. K. Fehmita Mubin, J. Gov. 4, (2019)

10. W. K. Utami and M. R. Godjali, J. Gov. 5, (2020)

11. I. Widianingsih, R. Riswanda, and C. Paskarina, J. Gov. 5, (2020)

12. D. Gustiani and R. A. Dwiningtias, Ijd-Demos 2, 249 (2020)

13. M. D. Hikmawan, I. Indriyany, and Y. Mayrudin, in Proc. Int. Conf. Democr. Southeast Asia (ICDeSA 2019) (Atlantis Press, Paris, France, 2019)

14. A. Hamid, I. A. Indriyany, and M. D. Hikmawan, Otoritas J. Ilmu Pemerintah. 11, (2021)

15. J. R. Billings, J. Adv. Nurs. 31, 472 (2000)

16. C. L. Hartman, P. S. Hofman, and E. R. Stafford, Bus. Strateg. Environ. 8, (1999)

17. A. Dobson, Citizenship and The Environment (Oxford University Press, Oxford, 2004)

18. G. Smith, Liberal Democracy and Sustainability (Routledge, 2004)

19. A. Dobson and R. Eckersley, Political Theory and the Ecological Challenge (Cambridge University Press, Cambridge, 2006) 